\title{
O MISIUNE FECUNDĂ ÎN DIASPORA ROMÂNEASCĂ: EPISCOPIA ORTODOXĂ ROMÂNĂ A EUROPEI DE NORD (2008-2015) ${ }^{1}$
}

\author{
Alin Albu*
}

\begin{abstract}
A fecund mission in the Romanian diaspora: the Romanian Orthodox Diocese of Northern Europe (2008-2015). This paper approaches in a monographic way the recent history of the Romanian Orthodox Diocese of Northern Europe, created in 2008 for the spiritual needs of the Romanians settled in Scandinavia. Although facing the inherent difficulties of beginning, the Diocese shortly became a proof of the beauty of the Romanian Orthodoxy and spirituality, but also a counterfort of national conscience and identity. Merely ennumerating the pastoral, missionary, cultural and social achievements of the Diocese can confirm the missionary vocation of Bishop Macarie Drăgoi and of his priests in a pluriconfessional and multicultural space, in which the encounter between cultures and beliefs generates dialogue and collaboration.
\end{abstract}

Keywords: The Romanian Orthodox Diocese of Northern Europe, His Grace Macarie Drăgoi, Stockholm, Sweden, Scandinavia, mission, identity, dialogue, cohabitation.

* $\mathrm{PhD}$, Assistant Professor, Faculty of Orthodox Theology at "1 Decembrie 1918" University in Alba Iulia.

${ }^{1}$ Exprim și pe această cale caldele mele mulțumiri faţă de PS MACARIE Drăgoi, Episcopul Episcopiei Ortodoxe Române a Europei de Nord, pentru binecuvântarea de a realiza acest studiu şi pentru generozitatea şi promptitudinea în oferirea materialelor-suport, precum şi în oferirea sugestiilor.

De asemenea, mulțumirile mele se îndreaptă către părintele diacon Sorin Sîplăcan, secretarul PS Macarie, care mi-a pus la dispoziție informațiile necesare elaborării acestui studiu. 
Studiul de față reprezintă o recuperare micromonografică a unui model misionar care, deși de dată recentă, se dovedeşte a fi o formulă inteligentă şi fecundă de adaptare a misiunii Bisericii în „vremuri”, dar şi spaţii noi. Este vorba de Episcopia Ortodoxă Română a Europei de Nord, creată în 2008 pentru necesităţile spirituale ale românilor stabiliți în Scandinavia. Deşi cu greutăţi inerente începutului, prezența acesteia a devenit în scurt timp o mărturie despre frumusețea Ortodoxiei şi a spiritualității românești, dar şi un contrafort de conștiință şi identitate națională. Simpla enumerare a realizărilor pastoral-misionare, culturale şi sociale ale Episcopiei confirmă vocația misionară a Episcopului Macarie Drăgoi şi a preoților săi într-un spațiu pluriconfesional şi multicultural, în care întâlnirea dintre culturi şi credințe generează dialog şi colaborare.

Spațiul de față nu a permis detalierea activității tuturor parohiilor din cuprinsul eparhiei, ci doar expunerea reperelor şi a crâmpeielor din misiunea Centrului eparhial şi a chiriarhului, PS Macarie Drăgoi, un studiu ulterior având să completeze imaginea conturată mai jos.

\section{Precedente ale misiunii româneşti în Suedia şi Scandinavia}

Debutul relațiilor politice şi culturale româno-suedeze a avut loc la jumătatea secolului al XVII-lea, prin misiunea la Stockholm a diplomatului Nicolae Milescu-Spătarul, relațiile fiind extinse apoi la nivel bisericesc între Patriarhia Română şi Biserica Luterană Suedeză în timpul Patriarhului Miron Cristea şi consolidate ulterior în cadrul adunărilor Consiliului Ecumenic al Bisericilor şi prin vizitele oficiale reciproce.

Primele comunități parohiale ortodoxe româneşti din ținuturile scandinave au fost constituite în urmă cu patru decenii de către distinsul dascăl de istoria Bisericii româneşti, pr. prof. univ. dr. Alexandru I. Ciurea, care a organizat la 1 noiembrie 1971 în Stockholm prima parohie ortodoxă română din Scandinavia, cu 
hramul „Sfântul Mare Mucenic Gheorghe”. Aici s-a constituit totodată centrul administrativ al misiunii ortodoxe române din nordul Europei, parohia din capitala suedeză oferind asistență religioasă tuturor românilor din Suedia 2 .

La 1 aprilie 1974, părintele Alexandru Ciurea a înființat la Göteborg o filie care cuprindea 100 credincioşi - ce avea să devină distinctă la 28 martie 1976, iar în 1978, o nouă parohie la Malmö şi peste zece filiale ale parohiilor, în Danemarca, Norvegia şi Finlanda. Parohia din Malmö va fi prima care va deține o biserică proprie, sfințită în 1987 de către Patriarhul Teoctist Arăpaşu. La Stockholm, părintele profesor Alexandru Ciurea a înființat o bibliotecă românească şi revista „Candela", pe care a editat-o timp de cinci ani (1973-1978).

Comunitățile româneşti au continuat să se extindă şi după revenirea în țară a părintelui profesor, prin emigranții care au solicitat azil politic în timpul regimului comunist, iar după 1989, prin muncitorii şi studenții care s-au stabilit temporar sau definitiv în Nordul Europei ${ }^{3}$.

Cât priveşte jurisdicția, aceste parohii au fost aşezate la început sub oblăduirea directă a Patriarhiei Române, apoi sub cea a Arhiepiscopiei Române a Europei Occidentale de la Paris (din 1974), sub cea a Mitropoliei Ortodoxe Române a Europei Centrale şi Occidentale (din 1993), devenită ulterior Mitropolia Ortodoxă Română pentru Germania, Europa Centrală şi de Nord ${ }^{4}$. Treptat

${ }^{2}$ Despre misiunea scandinavă a părintelui profesor Alexandru Ciurea, a se vedea ultima monografie extinsă: Sorin Sâplăcan, Părintele Alexandru I. Ciurea - misionar in timutul scandinav, teză de licență susținută la Facultatea de Teologie Ortodoxă din Alba Iulia, 2014 (coord.: pr. lect. univ. dr. Alin Albu).

3 În 2010 trăiau în Suedia aproximativ 30.000 de români, în Danemarca aproximativ 6.000, în Norvegia 6.000, iar în Finlanda în jur de 3000; Pr. Daniel Dascălu (Copenhaga), Episcopia Ortodoxă Română a Europei de Nord, în volumul „Autocefalie şi responsabilitate”, București, Editura Basilica a Patriarhiei Române, 2010, p. 957.

${ }^{4}$ Preot Daniel Dascălu, art. cit., p. 959. 
însă, din cauza distanțelor considerabile, a extinderii comunităților româneşti în Scandinavia pe fondul mobilității demografice și a liberei circulații, s-a impus crearea unei eparhii distincte, dedicate acestui spaţiu, ceea ce s-a şi întâmplat în 2007.

\section{2. Începuturile Episcopiei Ortodoxe Române a Europei de Nord - înființarea; alegerea, hirotonia și întronizarea titularului; recunoaşterea de către autoritățile de stat ${ }^{5}$}

În şedința din 22 octombrie 2007, Sfântul Sinod al Bisericii Ortodoxe Române a decis, prin hotărârea nr. 4586/2007, înființarea şi organizarea Episcopiei Ortodoxe Române a Europei de Nord, cu sediul la Stockholm, ca eparhie sufragană a Mitropoliei Ortodoxe Române a Germaniei, Europei Centrale şi de Nord, cu jurisdicție asupra parohiilor din Suedia, Norvegia şi Danemarca $^{6}$.

În şedința din 5-7 martie 2008, Sfântul Sinod a ales ca episcop titular al noii eparhii, cu 42 de voturi din 45, pe Preacuviosul Arhimandrit Dr. Macarie Drăgoi, Mare Eclesiarh al

${ }^{5}$ La alcătuirea acestui studiu am folosit cinci surse principale: Pr. Daniel Dascălu (Copenhaga), art. cit., p. 951-972; Sorin Sâplăcan, Părintele Alexandru I. Ciurea - misionar în ținutul scandinav, teză de licență susținută la Facultatea de Teologie Ortodoxă din Alba Iulia, 2014 (coord. pr. lect. univ. dr. Alin Albu); „Candela Nordului”, revistă de spiritualitate și cultură editată de Episcopia Ortodoxă Română a Europei de Nord, Stockholm, Editura Felicitas, nr. 1-6, 2008-2013; Lista parohiilor şi mânăstirilor Episcopiei Ortodoxe Române a Europei de Nord, Activitatea pastoral-misionară a PS Episcop Macarie Drăgoi, Activitatea culturală şi socială din cadrul Episcopiei Ortodoxe Române a Europei de Nord, toate oferite în format electronic de către diac. Sorin Sîplăcan, secretarul PS-ului Macarie; http://episcopiascandinavia.se. Am specificat în notele de subsol doar prima sursă bibliografică amintită, celelalte fiind prea frecvent şi intercalat citate/folosite, precizarea lor punctuală riscând o aglomerare inutilă a aparatului critic.

${ }^{6}$ Preot Daniel Dascălu, art. cit., p. 960. 
Catedralei Mitropolitane din Cluj-Napoca ${ }^{7}$. La 2 mai 2008 a avut loc hirotonia întru episcop în catedrala din Cluj-Napoca, de către un sobor de 11 ierarhi din țară şi din diaspora, condus de ÎPS Bartolomeu, Mitropolitul Clujului, Albei, Crişanei şi Maramureşului, iar la 6 iulie 2008, întronizarea în Catedrala Episcopală a Bisericii Ortodoxe Sârbe din Stockholm, Sfânta Liturghie fiind oficiată de un sobor de 8 arhierei, în frunte cu IPPS Nifon, Arhiepiscopul şi Mitropolitul Târgoviştei şi Exarh Patriarhal, delegatul Preafericitului Părinte Daniel, Patriarhul României, alături de cei doi mitropoliți români ai Europei. La eveniment au participat reprezentanți ai autorităților de stat din România şi țările scandinave, reprezentanții Bisericilor Evanghelică Luterană şi Romano-Catolică, monahi şi credincioşi din țară şi din Peninsula Scandinavă, precum şi o delegație numeroasă de tineri îmbrăcați în port național, din Spermezeu, satul natal al Preasfințitului Macarie.

Statutul noii eparhii a fost aprobat de către Sfântul Sinod la 5 martie 2008, urmând ca alături de alte documente să fie prezentat autorităților Statului suedez în vederea obținerii personalității juridice $^{8}$. Au urmat dialoguri şi iniţiative de colaborare din partea PS Macarie cu autoritățile de stat, dar şi cu comunitățile parohiale româneşti constituite deja ca entităţi juridice, toate reclamând tact şi echilibru, pentru crearea şi menţinerea unui climat de încredere şi conlucrare.

La 12 decembrie 2009 s-au desfăşurat lucrările primei Adunări Eparhiale, în cadrul cărora s-au luat măsuri pentru finalizarea procedurii de recunoaştere juridică în conformitate cu legislația suedeză referitoare la libertatea religioasă şi regimul cultelor. Ca urmare a acestor demersuri, în anul 2010 noua

${ }^{7}$ Ibidem.

8 Arhiva Administrației Patriarhale, Fond Sectorul Comunități Externe, Procesul verbal al ședinţei Sfântului Sinod din 5 martie 2008 apud Ibidem, p. 963. 
episcopie a fost recunoscută şi înregistrată ca „unitate de cult”, cu titulatura în suedeză: „Rumänska Ortodoxa Stiftet för Norra Europa", integrând și acele comunități ortodoxe române grupate până atunci ca entități juridice înregistrate în Suedia sub denumirea de „Biserica Ortodoxă Română din Suedia şi Scandinavia” şi „Biserica Ortodoxă Suedeză”, precum şi parohiile româneşti care aveau să se înființeze în peninsula scandinavă, toate fiind direct supuse autorității canonice a ierarhului român .

Prin recunoaşterea oficială de către statul suedez, noua episcopie s-a putut manifesta ca entitate religioasă în relațiile cu întreaga societate scandinavă, recunoaşterea utilității ei în spațiul public favorizând inițierea unor proiecte comune cu autoritățile publice şi cu celelalte comunităţi creştine din Suedia.

Noua calitate s-a reflectat şi în art. 1 din Statutul pentru organizarea şi funcționarea Episcopiei Ortodoxe Române a Europei de Nord, a cărui modificare a fost aprobată de Sfầntul Sinod în şedința din 10-11 februarie 2010: „Episcopia Ortodoxă Română a Europei de Nord este persoană juridică compusă din unitățile bisericești: «Biserica Ortodoxă Română din Suedia şi Scandinavia», «Biserica Ortodoxă Suedeză»», parohiile existente şi cele care se vor înfiinţa" $"$.

\section{PS Dr. MACARIE Drăgoi - primul episcop ortodox român din Scandinavia - fişă biografică}

Macarie Drăgoi (din Botez, Marius-Dan), Născut la 9 mai 1977, în Căianu Mic, jud. Bistrița-Năsăud, ca cel de-al treilea copil în familia credincioşilor ortodocşi Vasile şi Ana din localitatea Spermezeu, jud. Bistrița-Năsăud. Clasele I-VII le urmează între

${ }^{9}$ Ibidem, p. 964.

10 Arhiva Administrației Patriarhale, Fond Sectorul Comunităţi Externe, Şedinţa Sfântului Sinod din 10-11 februarie 2010, temei nr. 9668/2009 apud Ibidem. 
1983-1990 la Şcoala Generală din Spermezeu, iar clasa a VIII-a (1990-1991) la Şcoala Generală „Sfântul Constantin Brâncoveanu” din Cluj-Napoca. Studii liceale la Seminarul Teologic „Sfântul Mitropolit Dosoftei" din Suceava (1991-1996), apoi Facultatea de Teologie a Universităţii „Babeş-Bolyai” din Cluj-Napoca (19962000); studii aprofundate, secția Teologie-Istorie, la Facultatea de Teologie din Cluj Napoca (2000-2001) şi studii de specializare la universitățile Leeds şi Durham, Marea Britanie (2004-2005); cursuri de doctorat la Facultatea de Studii Europene, Facultatea de Istorie şi la Facultatea de Teologie Ortodoxă, Universitatea „BabeşBolyai”, specialitatea Istoria Europei şi Istoria Bisericii Ortodoxe Române, cu noțiuni de Paleografie. La 2 aprilie 2008 a obținut titlul de doctor în Teologie, cu teza „Ortodocşi şi greco-catolici în Transilvania (1874-1916). Convergențe şi divergențe", iar la 20 septembrie 2014 a obținut titlul de doctor în Istorie cu teza „Istorie, cultură şi spiritualitate în zona Văilor Țibleşului".

A fost secretar de cabinet al Mitropolitului Bartolomeu Anania (1998-2003), redactor la Radio Renaşterea din Cluj-Napoca (19992002) şi Radio Reîntregirea din Alba Iulia (2003-2005), profesor suplinitor de religie la Şcoala „Ioan Bob” din Cluj Napoca (2001). La 23 iunie 2003, în Mănăstirea „Sfântul Ioan Botezătorul” din Alba Iulia, a fost tuns în monahism de către Arhiepiscopul locului, IPS Andrei Andreicut, primind numele de Macarie, avându-l ca naş de călugărie pe Episcopul Vasile Fluieraş Someşanul. În aceeaşi mănăstire, la Liturghia Praznicului „Naşterii Sfântului Ioan Botezătorul" din 24 iunie 2003, a fost hirotonit ierodiacon de către IPS Arhiepiscop Andrei Andreicuț. La 6 ianuarie 2004, de praznicul Botezului Domnului, a fost hirotonit ieromonah de către IPS Andrei Andreicuț, în Catedrala arhiepiscopală din Alba Iulia, pe seama acestei catedrale, în paralel îndeplinind atribuțiile de preparator şi duhovnic la Facultatea de Teologie Ortodoxă din Alba Iulia. În perioada studiilor din Anglia a întemeiat prima parohie românească din nordul Marii Britanii, la Mirfield-Leeds, cu hramul „Sfântul Cuvios Macarie cel Mare”, şi două filii la Manchester şi Corby. La 24 aprilie 2005 a fost hirotesit de IPS Bartolomeu 
Anania, protosinghel şi eclesiarh al Catedralei mitropolitane din Cluj-Napoca, iar la 16 martie 2008, în aceeaşi catedrală, a fost hirotesit arhimandrit. Între 2005-2008 a fost eclesiarh al Catedralei mitropolitane şi profesor-duhovnic al Seminarului Teologic din Cluj-Napoca. La 5 martie 2008 a fost ales Episcop al Episcopiei Ortodoxe Române a Europei de Nord de către Sfântul Sinod al Bisericii Ortodoxe Române.

Activitatea sa ştiințifică însumează 10 volume $^{11}$, peste 40 de studii de teologie, istorie şi etnografie, în reviste de specialitate şi volume colective din țară şi din străinătate, precum şi peste 100 de articole, recenzii şi interviuri în diferite periodice bisericeşti şi de cultură.

${ }^{11}$ Spermezeu - străvechi sat de la poalele Tibleşului. Monografie istorică, Cluj-Napoca, Editura Limes, 2001; Folclor muzical din Spermezeu. Schiță monografică, Cluj-Napoca, Editura Limes, 2005; Folclor poetic din Spermezeu. Texte rituale, epice, lirice et varia, Cluj-Napoca, Editura Limes, 2005; Ler Sfântă Mărie. Colinde de pe văile Țibleşului, Cluj-Napoca, Editura Renaşterea, 2005; Ortodocşi şi greco-catolici în Transilvania 1867-1916). Convergente şi divergențe, Cluj-Napoca, Editura Presa Universitară Clujeană, 2011; Ortodocşi şi greco-catolici in Transilvania (1867-1916). Contributii documentare. Schimbarea identitătii confesionale. Cazurile Apahida şi Băgaciu, Vol I/1; Cazurile Rogoz şi Gothatea, Vol I/2; Cazul Stârciu cu filia Pria, Vol I/3; Cazul Săcel cu filia Dragomireşti, Vol I/4, Cluj-Napoca, Editura Presa Universitară Clujeană, 2013; An artisan of Christian Unity between North and East-Nathan Söderblom. His correspondence with Orthodox personalities (1896-1931). Edited by His Grace Macarie Dragoi, Romanian Bishop of Northern Europe. Foreword by His Beatitude Daniel, Patriarch of the Romanian Orthodox Church, Stockholm, Felicitas Publishing House, 2014. 


\section{Organizarea administrativă a Episcopiei Ortodoxe Române a Europei de Nord}

\subsection{Centrul Eparhial şi reşedința episcopală}

Centrul Eparhial şi reşedinţa episcopală s-au aflat inițial la 70 de $\mathrm{km}$ de oraşul Stockholm, Suedia, până în 2011, când a fost achiziționat un complex de clădiri la $24 \mathrm{~km}$ de capitala suedeză, care găzduieşte atât reşedința episcopală, cât şi departamentele administrative şi cultural-misionare ale Episcopiei. În cadrul Centrului eparhial ființează un Centru de Tineret, un Centru de pelerinaj şi mânăstirea cu hramul „Sfântul Apostol Andrei şi Sfinții Voievozi Români Ştefan cel Mare, Neagoe Basarab şi Constantin Brâncoveanu cu fiii Constantin, Ştefan, Radu, Matei şi sfetnicul Ianache", patronii spirituali ai eparhiei. În cadrul mânăstirii funcționează ateliere de pictură, vitraliu, broderie şi veşminte. Clerul episcopiei este alcătuit din 26 preoți şi un diacon.

\subsection{Parohii}

Actualmente, în cele 3 țări scandinave există 29 parohii cu 10 filii, precum şi două mânăstiri, multe purtând, pe lângă hramurile îndătinate, şi nume de sfinți români (ierarhi din cele trei provincii istorice româneşti, sihaştri, cuvioşi şi cuvioase, martiri şi mărturisitori români şi daco-romani) - evident, expresia evlaviei aparte a ierarhului faţă de aceste chipuri sfinte -, dar şi câteva de sfinți scandinavi ${ }^{12}$ :

- în Suedia, 12 parohii cu 7 filii (Stockholm - 3 parohii, Borås, Göteborg, Halmstad - filie Göteborg, Helsingborg - filie Malmö, Hillerstorp - filie Jönköping, Jönköping, Kristianstad - filie Sölvesborg, Ktintehamn - Insula Gotland, Linköping - filie

\footnotetext{
${ }^{12}$ Lista parohiilor şi mânăstirilor Episcopiei Ortodoxe Române a Europei de Nord (în format electronic), oferită de diac. Sorin Sîplăcan, secretarul PS Macarie Drăgoi.
} 
Stockholm, Malmö, Örebro - filie Stockholm, Sölvesborg, Umeå, Uppsala, Västerås, Växjö);

- în Danemarca, 8 parohii cu 3 filii (Copenhaga, Aalborg, Århus, Esbjerg - filie Herning-Ikast, Herning-Ikast, Holstebro - filie Herning-Ikast, Odense, Roskilde, Skagen - filie Aalborg, Sønderborg, Viborg);

- în Norvegia, 9 parohii (Oslo, Ålesund, Bergen, Førde, Haugesund, Kristiansand, Stavanger, Tromsø şi Trondheim);

- două mânăstiri: „Sfântul Apostol Andrei şi Sfinții Voievozi Români” de la Centrul Episcopal din Stockholm (2008); „Sfinții Cuvioşi Macarie Romanul şi Ioan Iacob de la Neamț" din Ikast, Danemarca - prima mănăstire ortodoxă română din Danemarca, inaugurată la 19 octombrie 2014.

\section{Locaşuri de cult şi proiecte de biserici}

În spațiul scandinav există puține cazuri în care comunitătile parohiale româneşti dețin un locaş de cult propriu, în rest slujirea liturgică desfăşurându-se în biserici închiriate sau primite de la Biserica Luterană, cum se întâmplă în general în Suedia, sau de la Biserica Romano-Catolică, cum este cazul în Danemarca, deşi aici catolicismul este în minoritate ${ }^{13}$. Există şi câteva situaţii în care s-a reuşit obţinerea de teren pentru ridicarea unui nou locaş, sau concesionarea unei biserici, care să fie adaptată nevoilor de cult ortodoxe.

Parohia din Malmö, Suedia, a fost prima care a deținut o biserică proprie, sfințită la 27 septembrie 1987 de către Patriarhul Teoctist. Pictura acestui locaş se află în faza de finalizare.

În Göteborg, Suedia, s-a primit spre folosință din partea Bisericii Luterane un locaş de cult, care a fost ulterior adaptat şi împodobit cu iconostas şi pictură bizantină, fiind târnosit la 6 decembrie 1992 de către ÎPS Daniel, Mitropolitul Moldovei ${ }^{14}$.

${ }^{13}$ Preot Daniel Dascălu, art. cit., p. 968.

${ }^{14}$ Ibidem. 
În Jönköping, Suedia, comunitatea românească a intrat în posesia unei biserici luterane la 1 martie 2014, de atunci fiind demarate lucrări de înfrumusețare a locaşului de cult.

În Herning-Ikast, Danemarca, parohia românească a preluat la 15 mai 2013 o biserică luterană destinată activităţilor misionare cu tinerii, din momentul intrării în posesie fiind demarate ample lucrări de amenajare interioară.

În urma discuțiilor pe care PS Macarie le-a avut cu oficialitățile din oraşul Sölvesborg, Suedia, s-a reuşit la începutul anului 2010 achiziționarea unui teren de $2490 \mathrm{de} \mathrm{mp}$, în primăvara anului 2015 fiind finalizate lucrările de construcție a unei biserici de lemn, de către o echipă de meşteri din Ieud, Maramureş ${ }^{15}$.

În parohia „Adormirea Maicii Domnului” din BredängStockholm, Suedia, este în derulare un proiect de amploare, care include o biserică tradițională şi un aşezământ pastoral-cultural pe un teren de $9000 \mathrm{mp}$, concesionat de către Primăria cartierului Bredäng din Stockholm. La punerea pietrei de temelie din 26 aprilie 2009, slujba de sfințire a fost săvârşită de Înaltpreasfinţitul Laurențiu, Mitropolitul Ardealului, împreună cu Preasfințitul Părinte Macarie, Episcopul Europei de Nord ${ }^{16}$.

\subsection{Centrul de tineret „Sfântul Voievod Ştefan Cel Mare”}

La inițiativa şi cu binecuvântarea PS Macarie a luat ființă Centrul de tineret "Sfântul Voievod Ştefan cel Mare”, al cărui obiectiv este acela de a-i coopta pe tinerii români din țările scandinave în proiecte care să-i apropie sufleteşte, să le descopere şi să le aprofundeze tradițiile ortodoxe româneşti, dar mai ales să-i implice în viața comunităților parohiale ${ }^{17}$.

${ }^{15}$ Ibidem, p. 969.

${ }^{16}$ Ibidem, p. 968-969.

${ }^{17}$ Ibidem, p. 965. 
Centrul de tineret are filiale în fiecare parohie, cele din apropierea marilor centre universitare scandinave bucurându-se de prezența cea mai numeroasă a tineretului.

Activitatea Centrului conţine o paletă largă de direcții: întruniri catehetice, tabere de vară şi de iarnă în țările scandinave, pelerinaje şi întâlniri, concerte susţinute de Grupul coral „Credo" al episcopiei, atât în biserici şi instituții culturale, cât şi în aşezăminte sociale şi spitaliceşti, proiecte în atelierele de pictură, vitraliu, broderie şi sculptură, toate vizând implicarea tinerilor în viața liturgică, misionară şi filantropică a comunitătilor, dar şi stabilirea unor legături de suflet între tinerii din diferite parohii ale Episcopiei şi cei din alte eparhii ortodoxe ${ }^{18}$.

Tot în cadrul Centrului de tineret funcționează sectorul şcolilor parohiale, care coordonează în unitate didactică şi educațională proiectele şcolilor duminicale, în cadrul cărora se organizează cursuri pe segmente de vârstă şi pe categorii tematice, astfel încât copiii născuți sau crescuți în nordul Europei să nu piardă continuitatea de limbă, neam şi credință ${ }^{19}$.

În fiecare an PS Macarie organizează întâlniri cu reprezentanții tineretului ortodox român din nordul Europei. Prima întâlnire a avut loc în 2009 la Oslo (Norvegia), când Preasfinția Sa a vorbit despre actualitatea omiliei către tineri a Sfântului Vasile cel Mare. A doua întâlnire a fost organizată la 9 mai 2010 tot la Oslo, cu tema: „Crezul Bisericii şi sensul vieții noastre”, acum fiind prezenți şi PS Ambrozie, Episcopul Giurgiului şi PS Emilian Lovişteanul, Episcopul-vicar al Arhiepiscopiei Râmnicului. Alte Adunări generale ale tinerilor din Episcopia Ortodoxă Română a Europei de Nord au avut loc la Mănăstirea Tismana (11-17 iulie 2011), la Ikast, Danemarca (3-6 mai 2012), având tema: „Tinerețea care alină boala: grija tinerilor față de cei aflați în suferință", Mănăstirea Caraiman (28 ianuarie - 4 februarie 2013), Copenhaga,

\footnotetext{
${ }^{18}$ Ibidem.

${ }^{19}$ Ibidem, p. 966.
} 
Danemarca, la 30 noiembrie 2013 şi 17-18 octombrie 2014, cu tema: „Sfinții Martiri Brâncoveni, pildă de viață şi mărturisire”.

\subsection{Centrul de Pelerinaje „Sfântul Antipa de la Calapodeşti”"}

Acest Centru a organizat mai multe pelerinaje la hramul episcopiei, la hramurile parohiilor, pe teritoriul celor trei țări scandinave, pe urmelor sfinților care au viețuit în aceste ținuturi, la mănăstiri şi biserici din România şi din Locurile Sfinte (la sfinţii vindecători din Grecia, la Ierusalim, Sinai, Capadocia). Conştient de faptul că pelerinajele sunt prilej de întărire duhovnicească personală, dar şi de coeziune a comunităților, manifestând o adâncă evlavie față de sfinții purtători de moaşte, PS Macarie a inițiat şi condus mai multe pelerinaje şi tabere cu tinerii şi credincioşii din ținuturile scandinave:

- în Eskilstuna, la moaştele Sfintei Ana de Novgorod, păstrate în biserica ortodoxă suedeză din acest oraş (4 aprilie 2009);

- la Husaby, la Fântâna Sfântului Sigfrid, Luminătorul Suediei (21 mai 2009);

- în perioada 27 mai - 5 iunie 2009, PS Macarie, împreună cu un grup de preoți şi credincioşi români din Suedia, Norvegia şi Danemarca, a participat la pelerinajul organizat de Patriarhia Română în Asia Mică, pe urmele Sfinților Capadocieni. Grupul de pelerini a participat şi la sfintele slujbe din Constantinopol şi Capadocia, oficiate de Sanctitatea Sa Bartolomeu, Patriarhul Constantinopolului, şi Preafericirea Sa Daniel, Patriarhul României;

- la Trondheim, pe urmele Sfântului Rege Martir Olav, creştinătorul Norvegiei (26-30 iulie 2009)

- la Växjö, Suedia, în oraşul Sfântului Sigfrid, creştinătorul Suediei, împreună cu ÎPS Andrei, Arhiepiscopul Alba Iuliei (4 octombrie 2009);

- la biserica romano-catolică din Oslo, Norvegia, unde sunt păstrate moaştele Sfântului Rege şi Martir Olav (9 mai 2010). 
- în perioada 18-28 septembrie 2010 PS Macarie a condus în Țara Sfântă şi la Muntele Sinai un grup impresionant de pelerini, format din preoți și credincioși din eparhie;

- în perioada 17-26 septembrie 2011, 40 de credincioşi şi Şase preoți din Episcopia Europei de Nord, însoțiți de Preasfințitul Episcop Macarie, au participat la un pelerinaj în România cu tematica „Familia creştină”, având ca scop redescoperirea valorilor profunde ale familiei creştine, prin rugăciune şi convorbiri duhovniceşti cu ierarhi români şi cu duhovnici din diverse mănăstiri româneşti;

- la 4 noiembrie 2011 un grup de pelerini format din ierarhi şi preoți ortodocşi, copți şi sirieni din Suedia şi din reprezentanţi ai Institutului de Studii Ortodoxe din Stockholm, condus de Preasfințitul Macarie, a vizitat Facultățile de Teologie Ortodoxă din Iaşi şi Bucureşti;

- la Trondheim, Norvegia, PS Macarie împreună cu clerici şi credincioşi ortodocşi de diferite naţionalităţi au participat la tradiționalul pelerinaj în cinstea Sfântului Rege Martir Olav (27-28 iulie 2012);

- la Centrul social-pastoral „Sfânta Cruce” al Mănăstirii Caraiman - Buşteni (jud. Prahova) şi la Catedrala Patriarhală - un grup de 40 de tineri români din Scandinavia, dar şi suedezi, danezi şi norvegieni convertiţi la Ortodoxie, conduşi de PS Macarie (2 februarie 2013) ${ }^{20}$.

\section{Aspecte misionar-pastorale}

Lucrarea misionar-pastorală a unei eparhii este cel mai dificil de sintetizat şi, cu atât mai mult, de cuantificat. Căci nu doar realizările punctuale, adeseori nici chiar calitatea acestora, sunt cele care asigură „succesul”, adică rodirea duhovnicească, ci harul lui Dumnezeu şi voința / buna inimă a oamenilor, dorul lor de a „1̂mpământeni” împărăția cerească. De aceea, orice intenție de

${ }^{20}$ Ibidem, p. 966-967. 
inventariere de acest fel are de plano limitele ei. Totuşi, acolo unde există bună vrere şi bună făptuire a slujitorilor altarelor, rodul nu va întârzia să apară, fie vizibil şi „cuantificabil”, fie tainic, în inimile credincioşilor.

Este şi cazul PS Macarie, despre al cărui zel misionar stau mărturie zecile de mii de kilometri parcurşi nu doar în cele trei regate (Suedia, Norvegia şi Danemarca), ci şi în Finlanda şi Islanda, oferind comunităților româneşti nu doar bucurie şi mângâiere duhovnicească, ci purtând cu şi în sine şi chipul şi simțământul genuin al lui „Acasă”, al acelei matrici spirituale şi etnice care oferă românilor din diaspora cel mai puternic suport identitar.

$\mathrm{Nu}$ întâmplător, programele pastorale şi sociale pentru susținerea valorilor creştine sunt dublate de proiecte de valorificare a spiritualității şi culturii românești! Înşişi colaboratorii PS Macarie, preoți şi credincioşi, au sesizat „,puterea-i de a imprima tuturor acțiunilor şi proiectelor desfăşurate în cadrul tinerei Episcopii, un puternic suflu românesc, pătruns de Ortodoxia dreptmăritoare" 21 , ceea ce nici nu surprinde, având în vedere palmaresul ştiințific al ierarhului, ca unul care deține diplome doctorale în istoria Bisericii şi a mentalului românesc. $O$ altă trăsătură care izvorăşte din acelaşi profil cultural este accentuata dimensiune culturală amprentată actului pastoral, regăsită în preocupările pentru manifestări ştiinţifice, cultural-artistice, editoriale etc.

Toate acestea însă fără detaşarea rece, specifică intelectualului de birou, ci, dimpotrivă, într-o împletire cu viața pastorală, cu pulsul comunităților. O probează prezența ierarhului în fiecare parohie de mai multe ori pe parcursul fiecărui an, ceea ce oferă avantajul observării şi evaluării activității pastoral-misionare a fiecărei parohii.

Gestionând situții specifice, ca fenomenul căsătoriilor mixte, integrarea credincioşilor neortodocşi, dar şi a celor botezați în credința ortodoxă, dar necunoscători ai credinței, acomodându-se

${ }^{21}$ Ibidem, p. 972. 
realităților sociale ale începutului de mileniu care au impus identificarea de noi priorități şi mecanisme misionare în diaspora într-un cuvânt, înțelegând „vremurile”, dar şi „locurile” -, diversificând şi intensificând programele pastorale, Episcopia Ortodoxă Română a Europei de Nord s-a manifestat chiar de la început ca o prezență dinamică în viața comunităților româneşti din spațiul scandinav, iar întâistătătorul ei a păşit pe urmele misionarilor de acum un mileniu, dar şi pe ale distinsului profesor unviversitar, pr. Alexandru Ciurea, primul misionar român în Scandinavia. Suntem convinşi că pasiunea şi specializarea profesională comune celor doi nu reprezintă o simplă coincidență, ci este lucrarea Proniei care face legătura între cele două misiuni şi cei doi misionari.

\section{Aspecte culturale}

\subsection{Conferințe şi manifestări ştiințifice}

O preocupare constantă a PS Macarie, ca unul format în mediu eminamente universitar, unde a dobândit alura şi reflexele omului de cultură, a fost cooptarea unor ierarhi, profesori de teologie şi duhovnici, care au susținut mai multe conferinţe în mediile universitare şi în comunitățile parohiale ale celor trei țări scandinave $^{22}$. La acestea se adaugă conferinţele, întrunirile şi simpozioanele în colaborare cu alte instituții din țările scandinave. Pe toate PS Macarie le-a încurajat şi pe o parte le-a susținut personal. $\mathrm{N}$-a lipsit nici implicarea preoților şi a credincioşilor în organizarea şi găzduirea acestora, interesul pentru astfel de manifestări culturale crescând an de an:

- $\quad$ la 28 septembrie 2008, respectiv 5 octombrie 2008, au avut loc manifestări duhovniceşti şi culturale la Malmö, respectiv Göteborg, Suedia, cu ocazia aniversării a două mari acte editoriale

${ }^{22}$ Ibidem, p. 969. 
din istoria culturii române: Liturghierul, 1508, şi Biblia, 1688. PS Macarie a subliniat însemnătatea deosebită a acestor momente fundamentale pentru istoria, cultura şi spiritualitatea românească;

PS Macarie, Episcopul Europei de Nord: Cultura discernământului la Sfântul Vasile cel Mare şi la ceilalți Sfinți Capadocieni, Copenhaga, 29 ianuarie 2009;

la 10 februarie 2009, la Ambasada României din Stockholm

a avut loc vernisajul unei expoziții de documente diplomatice referitoare la Unirea din 1859 - printre vorbitori s-a aflat şi PS Macarie, care a evidențiat contribuția fundamentală a Bisericii Ortodoxe Române la realizarea Unirii Principatelor Române;

- $\quad$ ÎPS Laurențiu, Mitropolitul Ardealului: Sfântul Vasile cel Mare: De la Liturghie la filantropie, Stockholm, 26 aprilie 2009;

PS Macarie: Maica Domnului în scrierile Sfântului Vasile cel Mare, Stockholm, 9 mai 2009;

- $\quad$ Pr. prof. univ. dr. Ştefan Buchiu: Triptic capadocian. Sfânta Macrina şi frații ei, Sfinții Vasile cel Mare şi Grigorie de Nyssa, Stockholm, 19 iulie 2009;

în zilele de 26-28 iulie 2009 s-au desfăşurat lucrările Simpozioului internațional cu tema „Locurile sfinte - zone pentru conflict sau pentru dialog?", la care au participat reprezentanți ai Bisericilor Ortodoxă, Catolică, Armeană şi Protestantă, precum şi ai comunităţilor iudaică şi musulmană. Biserica Ortodoxă a fost reprezentată de patru delegați (Constantinopol, Serbia, România şi Bulgaria), printre care şi PS Macarie;

ÎPS Andrei, Arhiepiscopul Alba-Iuliei: Sfinții Capadocieni modele de viețuire creştină, Jönköping, Suedia, 3 octombrie 2009; - Părintele Ioan Cojanu, Starețul Mănăstirii „Sfântul Ioan Botezătorul" din Alba Iulia: mai multe conferințe în cadrul parohiilor ortodoxe române din Stockholm, 5-7 martie 2010;

în perioada 14-15 mai 2010, în oraşul Eskilstuna din Suedia s-a desfăşurat prima ediție a Conferinței Cadrelor Didactice de Limba şi Literatura Română din Scandinavia, cu tema „Învățământul românesc în context european”, în deschiderea 
conferinței Preasfințitul Macarie rostind o alocuțiune cu titlul „Limba română, matcă a spiritualității româneşti în cult şi cultură”;

- Pr. prof. univ. dr. Alexandru Moraru de la Facultatea de Teologie Ortodoxă din Cluj-Napoca: Comuniune şi responsabilitate in Biserica Ortodoxă Română: Autocefalie şi Patriarhie, Stockholm, 18 iulie 2010;

Alba Iulia, peste două milenii de istorie. Cetatea medievală Alba Carolina", Stockholm, 22 august 2010 - prelegeri susținute de tineri licenţiați în istorie ai Universitatii „1 Decembrie 1918” din Alba Iulia, care fac parte din comunitatea românească din capitala Suediei. PS Macarie a vorbit despre moştenirea ortodoxă a fostului scaun mitropolitan al Transilvaniei şi despre Catedrala Reîntregirii;

la 7 octombrie 2011, la sediul Ambasadei României din Stockholm, s-a desfăşurat a doua ediție a Conferinței Cadrelor Didactice de Limba şi Literatura Română din Suedia, la care Preasfințitul Episcop Macarie a participat cu alocuțiunea „Păstrarea identităţii româneşti prin limbă, credinţă şi cultură în familia creştină";

PS Macarie: despre Sfântul Ignatie Teoforul, la Institutul de Studii Ortodoxe din Stockholm, 19 decembrie 2011;

la 23 februarie 2012, Preasfințitul Episcop Macarie a participat la întâlnirea cu profesorii şi cercetătorii Institutului de Studii Ortodoxe din Stockholm;

- la 26 mai 2012, cu prilejul lansării noii ediții a Sfintei Liturghii în limba suedeză, Centrul Cultural „Sofia” al Mitropoliei Ortodoxe Finlandeze din Helsinki, Finlanda, a organizat Sesiunea de comunicări cu tema „Limbă şi societate”, în cadrul căreia Preasfințitul Episcop Macarie a susținut prelegerea cu titlul „Biblie şi Liturghie la români";

- $\quad$ Episcopia Ortodoxă Română a Europei de Nord a organizat în 10 octombrie 2012, la sediul Institutului de Studii Ortodoxe din Stockholm, Sesiunea de comunicări ştiinţifice cu tema „Healing the World - a medical, ethical and sacramental perspective". La manifestare au participat profesori şi cercetători de la Institut, 
lucrările fiind coordonate de PS Macarie, care a prezentat comunicarea cu titlul „Iisus Hristos - Izvorul vindecărilor”;

la 16 noiembrie 2012, Facultatea de Teologie Ortodoxă din Bucureşti, în colaborare cu Episcopia Ortodoxă Română a Europei de Nord, a organizat Simpozionul comemorativ "Centenar Alexandru Ciurea (1912-2012)”. Prima prelegere a fost susținută de Preasfințitul Macarie, care a vorbit despre viața părintelui Alexandru Ciurea, referindu-se cu precădere la activitatea misionară pe care acesta a desfăşurat-o în țările scandinave, unde a pus bazele primelor comunități ortodoxe româneşti;

- la 20 decembrie 2012, Institutul de Studii Ortodoxe din Stockholm a organizat simpozionul ştiinţific cu tema „För världens helande - Healing the World - Vindecarea lumii". La lucrări au participat PS Macarie, profesori, medici, cercetători şi studenți din Suedia. Ierarhul român a susținut comunicarea cu titlul „Three perspectives of healing: spiritual, physical and social";

- $\quad$ PS Dositei al sârbilor din Scandinavia şi Marea Britanie şi PS Macarie al Europei de Nord au avut întâlniri la Stockholm cu teologi şi intelectuali din Suedia despre rolul şi locul Bisericii în societatea scandinavă (22-23 aprilie 2013);

- $\quad$ PS Macarie a participat la sesiunea de comunicări ştiințifice şi expoziția de icoane dedicate Sfinților Împărați, la Copenhaga, ambele organizate de Episcopia Ortodoxă Română a Europei de Nord, sub genericul: „Sfinții Împăraţi Constantin şi Elena în istoria şi spiritualitatea creştină" (23 octombrie 2013). Au conferențiat profesori şi cercetători de la Universitățile din Copenhaga şi Lund (Suedia);

- Simpozionul internațional „Sfinții Martiri Brâncoveni Mărturisitori ai credinței ortodoxe şi promotori ai culturii româneşti", Stavanger, Norvegia, 3 mai 2014, organizat de Episcopia Ortodoxă Română a Europei de Nord. PS Macarie a deschis lucrările cu comunicarea „Sfântul Constantin Brâncoveanul şi scandinavii", subliniind legăturile pe care Voievodului martir le-a avut cu scandinavii. Au participat Ambasadorul României în Regatul Norvegiei, Ambasadorul 
României pe lângă Sfântul Scaun şi profesori de teologie şi cercetători de la Universitățile din Oslo, Stavanger şi Bucureşti.

\subsection{Publicații religioase}

Activitatea editorială a Episcopiei este centrată pe publicarea revistei „Candela Nordului”, apărută pentru prima dată în urmă cu peste patru decenii, la inițiativa pr. prof. dr. Alexandru I. Ciurea, sub denumirea de „Candela”, şi care din 2008 a devenit publicația oficială a Episcopiei Ortodoxe Române a Europei de Nord (din 2012 apare în noua editură a eparhiei, „Felicitas”). Revista se doreşte a fi „spațiul prin care credincioşii şi preoții acestei eparhii să poată exprima şi păstra tradițiile şi valorile religioase şi naționale, precum şi să evidențieze aspecte ale conviețuirii paşnice pe meleagurile scandinave. De asemenea, această revistă se doreşte a fi şi o voce autorizată a Bisericii Ortodoxe Române în faţa desacralizării şi secularizării societăţii contemporane, cu atât mai mult cu cât societățile tehnologice au renunțat la valorile tradiționale şi religioase, în favoarea curentului consumist şi puternic egocentrist" 23 .

$\mathrm{Cu}$ o apariție anuală, cuprinzând o paletă diversificată de materiale bilingve (română şi engleză) - pastorale, studii, eseuri, poezii, in memoriam, dialoguri, evenimente, ştiri, agenda -, cu o ținută grafică excelentă, revista a devenit în scurt timp o emblemă pentru eparhie, apreciată nu doar de enoriaşii episcopiei, ci şi de personalități ale vieții culturale româneşti şi din străinătate.

$\mathrm{O}$ altă direcție editorială, atât cu impact cultural, cât mai ales misionar-pastoral, vizează publicarea de buletine parohiale, cu frecvență săptămânală sau lunară, de către fiecare parohie, utilitatea acestora fiind probată de informațiile utile oferite referitoare atât la viața religioasă a comunității, cât şi la problemele cu care se confruntă românii din fiecare zonă $\breve{~}^{24}$.

${ }^{23}$ Ibidem, p. 967-968.

${ }^{24}$ Ibidem, p. 968. 
Mai mult, convertind mijloacele moderne de comunicare în instrumente misionar-pastorale eficiente, fiecare parohie şi-a făcut cunoscută prezența în spațiul virtual, prin organizarea de site-uri proprii, care prezintă informații legate de activitatea desfăşurată în fiecare comunitate ${ }^{25}$. De asemenea, Centrul Eparhial are propiul site, în care sunt afişate toate informațiile importante, începând de la istoricul eparhiei şi până la agenda chiriarhului.

\subsection{Expoziții cu caracter religios şi popular}

O dimensiune aparte în cadrul activităţilor misionare şi culturale ale tinerei eparhii îl reprezintă expozițiile cu caracter religios şi popular organizate sub patronajul Episcopiei Ortodoxe Române a Europei de Nord sau cu colaborarea acesteia:

- expoziție de icoane bizantine româneşti pe lemn şi pe sticlă, cu tema „Tradiție şi identitate românească” - Galeriile de artă ale bisericii catolice din oraşul Århus, Danemarca, 23 aprilie 2009;

- expoziția cu tema „Prezenţa Sfinților Capadocieni în iconografia populară”, organizată de Episcopia Ortodoxă Română a Europei de Nord şi Ambasada României în Regatul Suediei, cu sprijinul Institutului Cultural Român de la Stockholm - Stockholm, 5 octombrie 2009 ;

- expoziție de artă tradițională românească sub genericul "Culorile timpului" - Galeria de artă a Ministerului Culturii din Oslo, 22 martie 2010. La eveniment au participat reprezentanți ai ambasadei României în Regatul Norvegiei, autorităti locale, precum şi Preasfințitul Macarie, care, în alocuțiunea rostită, a subliniat importanța manifestărilor de acest gen, care au menirea de a ne face cunoscuți lumii, dar şi de a ne regăsi identitatea în spațiul cultural european;

- expoziţie de icoane pe sticlă (icoane realizate după vechi izvoade transilvane, de pictorița Teodora Roşca), organizată de

${ }^{25}$ Ibidem. 
Episcopie în colaborare cu Casa de Cultură din Odder, Danemarca, 25 februarie 2012;

- expoziție de icoane pe sticlă (ediţia a III-a) - Odder, 23 noiembrie 2013. Preasfințitul Părinte Episcop Macarie a vorbit despre semnificația icoanei ortodoxe şi despre rolul icoanelor pe sticlă în istoria şi spiritualitatea românilor;

- la Centrul eparhial din Stockholm se află în derulare proiectul de punere în valoare a spiritualităţii şi culturii româneşti, prin constituirea unui fond etnografic care cuprinde obiecte şi costume tradiționale din toate zonele României, inclusiv piese primite de la românii din Basarabia şi Banatul sârbesc, toate adăpostite într-o încăpere tradițională românească de lângă Paraclisul episcopal.

\section{Aspecte social-filantropice}

În Duminica românilor migranți din 22 august 2010, PS Macarie a fost prezent în parohia „Sfântul Mare Mucenic Gheorghe" din Stockholm, unde a dat citire mesajului Preafericitului Părinte Patriarh Daniel la Duminica românilor migranți, intitulat „Când ne aflăm în străinătate să nu ne înstrăinăm de noi înşine!", şi le-a vorbit credincioşilor despre însemnătatea acestei duminici.

La 17 aprilie 2012, PS Macarie a participat la întâlnirea de Sfintele Paşti cu pensionarii români din capitala Suediei, unde a subliniat semnificaţiile duhovniceşti profunde şi multiple ale străvechilor obiceiuri pascale româneşti.

În unele parohii au fost derulate programe şi activităţi socialfilantropice, precum:

- "Picătura de jertfă care răscumpără oceanul nepăsării” colecte în bani, medicamente şi produse pentru ajutorarea unor familii sărace din România; 
- „Agapa fratelui" - acțiune duminicală, în biserică după Sfânta Liturghie, de colectare a alimentelor necesare pentru cantina socială;

- „In pace să ieşim" - misiune ce-i angajează pe credincioşi în vizitarea celor bolnavi şi singuri, împărtăşindu-le din darurile duhovniceşti pe care tocmai le-au primit la Sfânta Liturghie;

- „Consolidarea familiei” (din 2011) - proiect pastoral şi social pentru susținerea valorilor familiei creştine în societatea secularizată;

- Grupul coral „Credo” al Episcopiei a făcut vizite la spitalele din Stockholm unde a susținut concerte de cântări ortodoxe - proiect de misiune pastorală şi socială prin cântare.

- „O familie parohială pentru fiecare” - activitate care-i angajează pe credincioşi să ajute benevol copii orfani din România. În perioada 18-27 iunie 2013 s-a desfăşurat la Borås, Suedia, cu binecuvântarea şi susținerea Preasfinţitului Părinte Macarie, prima ediție a acestui proiect social, inițiat de parohia din Borås în colaborare cu Asociația românească „Unirea”. Obiectivul punctual a constat în oferirea unei vacanțe de vară în vestul Suediei pentru o grupă de copii aflați în grija Centrului de plasament din Lupeni (jud. Hunedoara), cu scopul creării unei legături de durată între comunitatea românească din această zonă şi copiii instituționalizaţi din România. Pe parcursul celor zece zile de vacanță, copiii au făcut cunoştință cu familiile româneşti rezidente în Suedia, prezentându-li-se modul în care credința şi tradițiile româneşti îşi păstrează particularitatea în contextul religios şi cultural scandinav. Au fost vizitate totodată numeroase obiective turistice din Suedia. 


\section{Aspecte naționale}

$\mathrm{Ca}$ unul care a urmat paralel cursuri doctorale de Istoria Bisericii Ortodoxe Române, dar şi de etnologie în cadrul universităţii napocense, irevocabil îndrăgostit de spiritualitatea şi cultura română - dovadă producția ştiințifică concretizată în numeroase volume, studii şi conferințe de profil -, PS Macarie s-a dovedit sensibil la dimensiunea națională a vieții româneşti din diaspora.

Astfel, PS Macarie a subliniat, încă din momentele hirotoniei şi întronizării, necesitatea ca, pe lângă împlinirea misiunii spirituale specifice, noua eparhie să devină şi un reper al identității naţionale: „socotim că episcopia noastră trebuie să devină un centru de cultură şi spiritualitate românescă" (Stockholm, 6 iulie 2008), dorindu-se astfel unitatea românilor răsfirați de voie şi de nevoie pe aceste melaguri (chiar şi a celor din afara României, cum este cazul românilor imigranți din Serbia - Voievodina şi Valea Timocului, stabiliți în Jönköping, Suedia, şi integraţi în parohia românească de aici). Nu este, aşadar, deloc întâmplătoare aşezarea tinerei episcopii sub ocrotirea a trei sfinți voievozi români, fapt care transmite ideea de unitate spirituală şi națională a fiilor acestei eparhii.

Un moment cu profunde semnificații naționale îl constituie an de an serbarea Zilei Naţionale a României, când PS Macarie săvârşește Te Deum, în prezența credincioşilor români şi a oficialităților române (ambasadori, membri ai Institutului Cultural Român etc.) şi străine, a reprezentanţilor altor culte, rostind alocuțiuni despre semnificația acestui mare moment din istoria poporului român (Oslo, 30 Noiembrie 2008; Stockholm, 1 decembrie 2010; Copenhaga, 1 decembrie 2013). De 1 Decembrie, 22 Decembrie şi de Ziua Eroilor, PS Macarie oficiază parastase pentru eroii României Mari sau ai Revoluției decembriste. Tot un reflex al acestei preocupări pentru prezervarea valorilor specific româneşti este şi iniţierea de către ierarh sau participarea acestuia la diverse expoziții de artă religioasă şi profană tradițională 
românească, ori încurajarea construirii de noi biserici în stil tradițional.

Spiritul românesc este menținut în cuprinsul eparhiei prin manifestări cultural-artistice care cuprind poezii, cântece şi creații autohtone, colinde, concerte de muzică bizantină, populară susţinute de Grupul coral "Credo" al Episcopiei şi de coruri din România, prin activitățile tineretului de la cercurile de etnografie şi folclor, unde s-au confecționat piese de port tradițional, de împodobire a locuinței şi a locaşului de închinare şi s-au organizat cursuri de dansuri populare româneşti. La Centrul eparhial din Stockholm este constituit un fond etnografic care cuprinde obiecte şi costume tradiţionale din toate zonele României, din Basarabia şi Banatul sârbesc.

\section{Legături cu Bisericile surori din țările de origine şi din diaspora}

Legăturile cu Bisericile surori realizate de Episcopia Europei de Nord s-au materializat în special în slujirile PS Macarie în Suedia, Islanda, Finlanda, Norvegia în biserici ale comunităţilor ruseşti şi sârbeşti sau în soboare de arhierei şi preoți ortodocşi români, sârbi, ruşi, suedezi:

- la 8 martie 2009, la Duminica Ortodoxiei, Bisericile Ortodoxe surori din Stockholm s-au organizat pentru a prăznui printr-o Liturghie comună unitatea de credință, în catedrala ortodoxă sârbă din Stockholm, slujba arhierească fiind oficiată de Preasfințitul Dositei, Episcopul sârbilor din Scandinavia şi Marea Britanie şi de Preasfinţitul Macarie, Episcopul românilor din Europa de Nord;

- în perioada 12-17 aprilie 2010, PS Macarie a făcut parte din delegația Departamentului pentru Studii Ortodoxe şi Cultură din Stockholm (din care fac parte reprezentanții comunităţilor ortodoxe din Peninsula Scandinavă), care a vizitat Patriarhia Rusiei, slujind la 13 aprilie 2010 împreună cu Sanctitatea Sa Chiril, Patriarhul Rusiei, în Catedrala 
Sfinții Arhangheli din Kremlin, necropola țarilor, şi transmițând acestuia mesajul Preafericirii Sale Daniel, Patriarhul României;

- la 10 ianuarie 2011 a avut loc constituirea Adunării Episcopilor ortodocşi din Peninsula Scandinavă, la Reşedința Mitropoliei Patriarhiei Ecumenice din Stockholm, la această primă reuniune PS Macarie participând alături de ierahul grec şi de cel sârb care păstoresc comunitățile din Scandinavia;

- la 13 martie 2011, de Duminica Ortodoxiei, Bisericile Ortodoxe surori din Stockholm au prăznuit prin slujire comună unitatea de credință în catedrala ortodoxă sârbă din Stockholm, unde au fost prezenți preoți greci, ruşi, sârbi, români, suedezi şi credincioşi ortodocşi de diferite naționalități din capitala Suediei;

- la 4 martie 2012, manifestarea duhovnicească din Duminica Ortodoxiei a fost găzduită de Episcopia Ortodoxă Română a Europei de Nord;

- la 5 octombrie 2014 PS Macarie a participat la târnosirea Catedralei "Sfântul Sava” din Stockholm a Episcopiei Ortodoxe Sârbe din Scandinavia şi Marea Britanie, într-un sobor condus de Patriarhul Irineu al Serbiei.

Într-un spațiu pluriconfesional şi multicultural, care impune de la sine dialogul şi chiar colaborarea, relațiile interconfesionale sau materializat prin întâlnirile numeroase ale PS Macarie cu întâistătătorii celorlalte Biserici creştine, unora dintre aceste comunități fiindu-le dăruite icoane cu sfinții lor protectori (de ex., icoana Sfântului Sigfrid, Luminătorul Suediei, dăruită de ierarhul român Catedralei din Växjö), cu alți oficiali ai Bisericilor creştine din Scandinavia, cu oameni de cultură, ori din administrația publică.

„Întâlnirea creştinismului răsăritean de sorginte apostolică a românilor cu creştinismul milenar al locuitorilor Scandinaviei a generat un firesc dialog duhovnicesc, izvorât din dorința comuniunii... şi a stabilirii unei atmosfere de pace şi bună voire 
între românii stabiliți în ținuturile nordice ale Europei şi popoarele care i-au primit în mijlocul lor" 26 .

De altfel, intenția aceasta, de dialog şi colaborare, a fost exprimată încă din momentele hirotoniei şi instalării ierarhului român: „o să avem ca prioritate atât unitatea întru credință a românilor din nordul Europei, cât şi statornicirea legăturilor de conviețuire şi colaborare cu celelalte comunități confesionale şi etnice..." 27 . Conştient de bunul nume pe care Biserica Ortodoxă Română şi l-a consolidat în spațiul scandinav, prin participarea mai multor ierarhi şi profesori români în decursul ultimului secol la manifestări cu caracter ecumenic organizate în Suedia şi prin vizitele reciproce ale întâistătătorilor Bisericilor ${ }^{28}$, PS Macarie a continuat această tradiție şi a îmbogățit-o prin deschiderea constant manifestată.

\section{Concluzii}

Programul pastoral-misionar al tinerei episcopii a fost trasat de titularul acesteia chiar de la întronizare: mărturisirea Ortodoxiei în spațiul nord-european, unitatea spirituală şi națională a românilor din diaspora scandinavă, relațiile de colaborare cu celelalte comunităţi confesionale şi etnice, atenţia fặă de problemele tinererilor şi față de păstrarea identităţii lor confesionale şi etnice ${ }^{29}$. O simplă enumerare a realizărilor pastoral-misionare, culturale şi sociale ale Episcopiei confirmă împlinirea acestor deziderate: Biserica a reuşit să-i adune pe români în jurul altarelor, oferindu-le nu doar repere spirituale, ci şi identitare, de limbă şi etnie.

\footnotetext{
${ }^{26}$ Ibidem, p. 971.

$27 \mathrm{http}: / /$ episcopiascandinavia.se/psmacarie/63-intromizarea/160-cuvantul-psepiscop-macarie, accesat la 1.05.2015.

${ }^{28}$ Preot Daniel Dascălu, art. cit., p. 972.

29 http://episcopiascandinavia.se/psmacarie/63-intromizarea/160-cuvantul-psepiscop-macarie, accesat la 1.05.2015.
} 
Accentuând deopotrivă ideea unității de credință şi de neam, cultivând virtuțile creştine, dar şi limba şi tradițiile româneşti, parohia diasporei a devenit cel mai puternic spațiu identitar din afara granițelor țării. Mai mult, dând mărturie despre frumusețea Ortodoxiei, Episcopia Europei de Nord îşi manifestă profunda vocaţie misionară într-un spațiu pluriconfesional şi multicultural, în care întâlnirea dintre culturi şi credințe generează dialog şi colaborare.

Departe de a se constitui ca o simplă recuperare monografică, ori ca o fişă quasibiografică a titularului eparhiei, deşi, în condițile de debut ale unei episcopii, cele două - biografia personajului şi istoria instituției - riscă în mai toate cazurile o suprapunere inevitabilă, prezentarea de față reiterează un parcurs impresionant, în care suntem martorii unei istorii în derulare, de conservare a unui ethos spiritual şi naţional, în ciuda tuturor pronosticurilor negative oferite de „trendul” secularist al zilei. Iar dacă ne gândim că, pe de o parte, acest efort de conservare a Ortodoxiei şi Românităţii peste graniţe tinde să se transforme chiar în avânt de promovare, iar pe de altă parte, că toate acestea se petrec departe de țară, de matricea spirituală şi culturală capabilă să ofere resorturile necesare „biruinței gândului”, nu putem decât să admirăm sârguința şi să ne încredințăm că Pronia dumnezeiască lucrează minunat în Biserică prin slujitorii Săi!

\section{Bibliografie}

1. Activitatea culturală şi socială din cadrul Episcopiei Ortodoxe Române a Europei de Nord, în format electronic, material oferit de diac. Sorin Sîplăcan, secretarul Preasfinţitului Macarie Drăgoi.

2. Activitatea pastoral-misionară a PS Episcop Macarie Drăgoi, în format electronic, material oferit de diac. Sorin Sîplăcan.

3. „Candela Nordului", revistă de spiritualitate şi cultură editată de Episcopia Ortodoxă Română a Europei de Nord, Stockholm, Editura Felicitas, nr. 1-6, 2008-2013. 
4. Dascălu, Daniel, Episcopia Ortodoxă Română a Europei de Nord, în volumul „Autocefalie şi responsabilitate”, volum apărut din iniţiativa şi cu binecuvântarea Preafericitului Părinte Daniel, Patriarhul Bisericii Ortodoxe Române, București, Editura Basilica a Patriarhiei Române, 2010, p. 951-972.

5. Lista parohiilor şi mânăstirilor Episcopiei Ortodoxe Române a Europei de Nord, în format electronic, material oferit de diac. Sorin Sîplăcan.

6. Sîplăcan, Sorin, Părintele Alexandru I. Ciurea - misionar în ținutul scandinav, teză de licență susținută la Facultatea de Teologie Ortodoxă din Alba Iulia, 2014 (coord.: pr. lect. univ. dr. Alin Albu).

7. http://episcopiascandinavia.se. 